Ciência e Natura, Santa Maria, v. 36 n. 2 mai-ago. 2014, p. 92-106

Revista do Centro de Ciências Naturais e Exatas - UFSM

ISSN impressa: 0100-8307 ISSN on-line: 2179-460X

\title{
Eficiência antimicrobiana e antiparasitária de desinfetantes na higienização de hortaliças na cidade de Natal - RN
}

\author{
Antimicrobial and antiparasitic efficiency of desinfectants in the sanitation of \\ vegetables in Natal city - RN
}

\author{
Ermeton Duarte do Nascimento ${ }^{1}$, Feliphe Lacerda Souza Alencar ${ }^{2}$ \\ 1,2Universidade Federal do Rio Grande do Norte, RN, Brasil
}

\begin{abstract}
Resumo
O presente estudo avaliou a eficiência do hipoclorito de sódio a 1\% e do ácido acético a 6,6\% (vinagre) na higienização de hortaliças in natura (alface, coentro, repolho e couve), provenientes de seis estabelecimentos comerciais, subdivididos em três supermercados e três feiras livres, localizados na cidade de Natal - RN, durante o período de junho a outubro de 2013. As amostras foram analisadas com o objetivo de descrever a presença de contaminantes e, em seguida, foram submetidas ao tratamento com soluções higienizantes. Para a análise parasitológica, utilizou-se os métodos de Hoffman, Pons e Janer (HPJ) e Faust. Para as análises bacteriológicas, foi utilizada a técnica do substrato cromogênico e posterior quantificação dos grupos coliformes, através da técnica do número mais provável (NMP). Para a análise estatística, além da estatística descritiva, foi utilizado o teste $t$ de student, considerando um $\alpha=0,05$. De um total de 24 amostras analisadas, em 41,7 \% foram encontradas formas parasitárias e o parasita mais prevalente foi o Endolimax nana (22,2\%). A análise dos grupos coliformes evidenciou que $100 \%$ das amostras do grupo controle estavam contaminadas por coliformes totais e $83,3 \%$ por coliformes termotolerantes. A alface apresentou o maior índice de contaminação por parasitas (50\%) entre as amostras do grupo controle, bem como as maiores médias de contaminação por coliformes totais e coliformes termotolerantes, acima de $2400 \mathrm{NMP} / 100 \mathrm{~mL}$ e $1356 \mathrm{NMP} / 100 \mathrm{~mL}$, respectivamente. As hortaliças provenientes das feiras livres apresentaram a maior prevalência de contaminação por parasitas ( $70 \%$ ), por coliformes totais $(53,7 \%$ ) e coliformes termotolerantes $(56,8 \%)$. Entretanto, esse estudo mostrou que não há diferença entre o risco de uma hortaliça adquirida em um supermercado ou feira livre estar contaminada por parasitas ( $p \leq 0,223)$, coliformes totais $(p \leq 0,193)$ elou coliformes termotolerantes $(p \leq 0,789)$. O uso do hipoclorito de sódio a $1 \%$ mostrou-se mais eficaz para a higienização de amostras contaminadas por parasitas $(p \leq 0,001)$, coliformes totais $(p \leq 0,000)$ e coliformes termotolerantes $(p \leq 0,001)$. Concluiu-se que as hortaliças podem ser grandes reservatórios de parasitas patogênicos e grupos coliformes, fazendo-se necessária a realização de medidas preventivas, direcionadas à qualidade higiênico-sanitária da água utilizada para irrigação das hortaliças e a correta desinfecção desses alimentos.
\end{abstract}

Palavras-chave: hortaliças, hipoclorito de sódio, ácido acético (vinagre), enteroparasitas e coliformes.

\begin{abstract}
This study evaluated the efficiency of sodium hypochlorite (1\%) and the acetic acid (vinegar) (6.6\%) in the sanitation of vegetables (lettuce, cabbage, cilantro and kale) from six establishments, subdivided into three supermarkets and three fairs, located in the city of Natal - RN, during the period from June to October, 2013. The samples were analyzed in order to describe the presence of contaminants and then were submitted to treatment with sanitizer solutions. For parasitological analysis, we used the methods of Hoffman, Pons and Janer (HPJ) and Faust. For bacterial analysis, we used the technique of chromogenic substrate and subsequent quantification of coliform groups by the most probable number (MPN). For statistical analysis, in addition to descriptive statistics, considering an $\alpha=0.05$, the Student t test was used. In total of 24 samples analyzed, in $41,7 \%$ were found parasitic forms and the most prevalent ones was the Endolimax nana (22.2\%). Among the samples analyzed, 100\% were contaminated with total coliforms and 83,3\% with thermotolerant coliforms. The lettuce had the highest rate of contamination by parasites (50\%), among the samples from the control group, as well as, the highest average of contamination by total coliforms and thermotolerants coliforms, above $2400 \mathrm{NMP} / 100 \mathrm{~mL}$ and $1356 \mathrm{NMP} / 100 \mathrm{~mL}$, respectively. The vegetables coming from the fairs had the highest prevalence of contamination by parasites (70\%), total coliforms (53.7\%) and thermotolerants coliforms (56.8\%).However, this study showed there is no difference between the risk of a vegetable bought in a supermarket or a fair being contaminated by parasites $(p \leq 0.223)$, total coliforms $(p \leq 0.193)$ and/or thermotolerants coliforms $(p \leq 0.789)$. The solution of sodium hypochlorite $(1 \%)$ was more efficient to contaminated samples by parasites $(p \leq 0.001)$, total coliforms $(p \leq 0.000)$ and thermotolerants coliforms $(p \leq 0.001)$. It is concluded that vegetables can be great reservoirs of pathogenic parasites and coliform groups, making necessary pre-emptive measures aimed at sanitary quality of water used for irrigation of vegetables and the proper disinfection of these foods.
\end{abstract}

Keywords: vegetables, sodium hypochlorite, acetic acid (vinegar), intestinal parasites and coliforms.

Recebido: 28/01/2014 Aceito: 20/02/2014 


\section{Introdução}

Na atualidade, o consumo de hortaliças representa uma das recomendações nutricionais da OMS, relacionadas à prevenção e ao controle de doenças crônicas não transmissíveis (DCNT), como obesidade, câncer, diabetes mellitus e doenças cardiovasculares. Entretanto, nos últimos anos, a importância do consumo das hortaliças e, consequentemente, dos benefícios que são gerados à saúde, vêm sendo gradativamente substituídos pelo risco da veiculação patogênica de microorganismos por esses alimentos (WHO, 2003; AZEVEDO, 2008).

Fatores agravantes têm contribuído, decisivamente, para a manutenção dessa problemática. De acordo como Fontes e colaboradores (2003), entre os principais fatores associados à contaminação de hortaliças destacam-se: a falta de condições sanitárias adequadas durante a produção, armazenamento, manipulação, distribuição e comercialização desses alimentos. Além disso, o local de comercialização desses gêneros, como as feiras livres, por exemplo, contribui significativamente para a disseminação de patógenos relacionados a doenças de veiculação alimentar (COUTINHO et al., 2008).

Ainda de acordo com Fontes e colaboradores (2003) e Coutinho e colaboradores (2008), a comercialização de hortaliças em feiras livres é um fator preocupante, visto que esses ambientes tornaram-se uma importante fonte de contaminação alimentar. Destaca-se, ainda, que a elevada incidência de contaminação alimentar nesses ambientes provém da falta de condições higiênicosanitárias das bancas de venda, da inadequação nos processos de higienização, bem como a falta de noções de segurança alimentar dos comerciantes e produtores desses alimentos. Tais condições fazem com que as feiras livres sejam consideradas locais favoráveis ao crescimento e proliferação de microrganismos (XAVIER et al., 2009).

Nesse contexto, a falta de condições sanitárias, observadas em muitas feiras livres, faz com que haja uma preferência de compra de gêneros alimentares em ambientes considerados mais adequados quanto às condições higiênico-sanitárias e apontam as redes de supermercado como esses ambientes. Entretanto, estudos realizados por Parteli e Gonçalves (2005), Santos (2007) e Marques e colaboradores (2002), em redes de supermercados, demonstram que há uma elevada prevalência de contaminação de hortaliças por enteroparasitas e por grupos coliformes nesses locais.

A problemática da contaminação microbiológica das hortaliças reforça a necessidade da implantação de meios profiláticos que garantam uma segurança alimentar ao consumo desses produtos. Entre os métodos mais comumente empregados pela população, destacam-se o emprego do hipoclorito de sódio e do ácido acético. O hipoclorito de sódio, conhecido popularmente como água sanitária, é considerado o agente sanitizante mais usado no Brasil, no entanto, a variação da concentração desse agente, durante o tratamento de hortaliças, pode comprometer a saúde do consumidor, devido à presença de derivados clorados nesses compostos (NASCIMENTO et al., 2003).

O ácido acético, conhecido como vinagre, também consiste em um agente higienizante de grande uso entre a população, no entanto, a sua composição, a base de ácidos orgânicos, e a variação da concentração do volume empregado durante a higienização de hortaliças, muitas vezes, pode comprometer a eficiência antimicrobiana e antiparasitária de sua ação (ANTONIOLLI et al., 2005; ANTUNES, 2009). Dessa forma, o emprego desses agentes pode contribuir, decisivamente, para o bloqueio epidemiológico do número de casos de doenças transmitidas por alimentos (RODRIGUES, 2004).

Sendo assim, o presente estudo teve como objetivo avaliar a eficiência da solução do hipoclorito de sódio a $1 \%$, conforme a portaria no 18 de 2008 do Centro de Vigilância Sanitária (CVS) da secretária de estado da saúde da ANVISA, sobre a higiene de hortifrutigranjeiros (CVS, 2008) e do ácido acético a 6,6\% (vinagre) (NASCIMENTO, et al., 2003), na higienização das hortaliças in natura: alface (Lactuca sativa L. var crispa), couve (Brassica oleracea L.. var. acephala.), repolho (Brassica oleraceae $\mathrm{L}$. var. capitata.) e coentro (Coriandrum sativum L.), provenientes de seis estabelecimentos comerciais, subdivididos em três supermercados e três feiras livres, localizados na cidade de Natal -RN, e descrever a prevalência da contaminação de cada tipo de hortaliça por protozoários, helmintos, coliformes totais e coliformes termotolerantes, bem como descrever e correlacionar o nível de contaminação microbiológica com o tipo de estabelecimento comercial e o tipo de hortaliça analisada.

\section{Materiais e métodos}

O presente estudo se caracteriza como seccional e analisou a prevalência da contaminação microbiológica de hortaliças, comercializadas em supermercados e feiras livres, durante o período de junho a outubro de 2013. Todos os locais de coleta analisados situam-se na cidade de Natal - RN, na região Nordeste do Brasil, que apresenta uma população estimada em 853.929 habitantes para o ano de 2013, com uma unidade territorial equivalente a $167.263 \mathrm{Km} 2$ (IBGE, 2010). Foram selecionados 6 estabelecimentos de venda de frutas, verduras e hortaliças, representados conforme a figura 1.

Em cada estabelecimento comercial foram selecionados quatro exemplares das seguintes hortaliças: alface (L. sativa L. var crispa), couve (B. oleracea L. var. acephala) repolho (B. oleraceae $\mathrm{L}$. var. capitata) e coentro (C. sativum L.), cultivadas pelo método tradicional.

Durante a higienização das hortaliças, foi utilizado: água destilada estéril, solução de hipoclorito de comercial a 1\% (constituído por um teor de cloro ativo equivalente entre $2 \%$ a 2,5\% p/p) e solução de ácido acético (vinagre) 


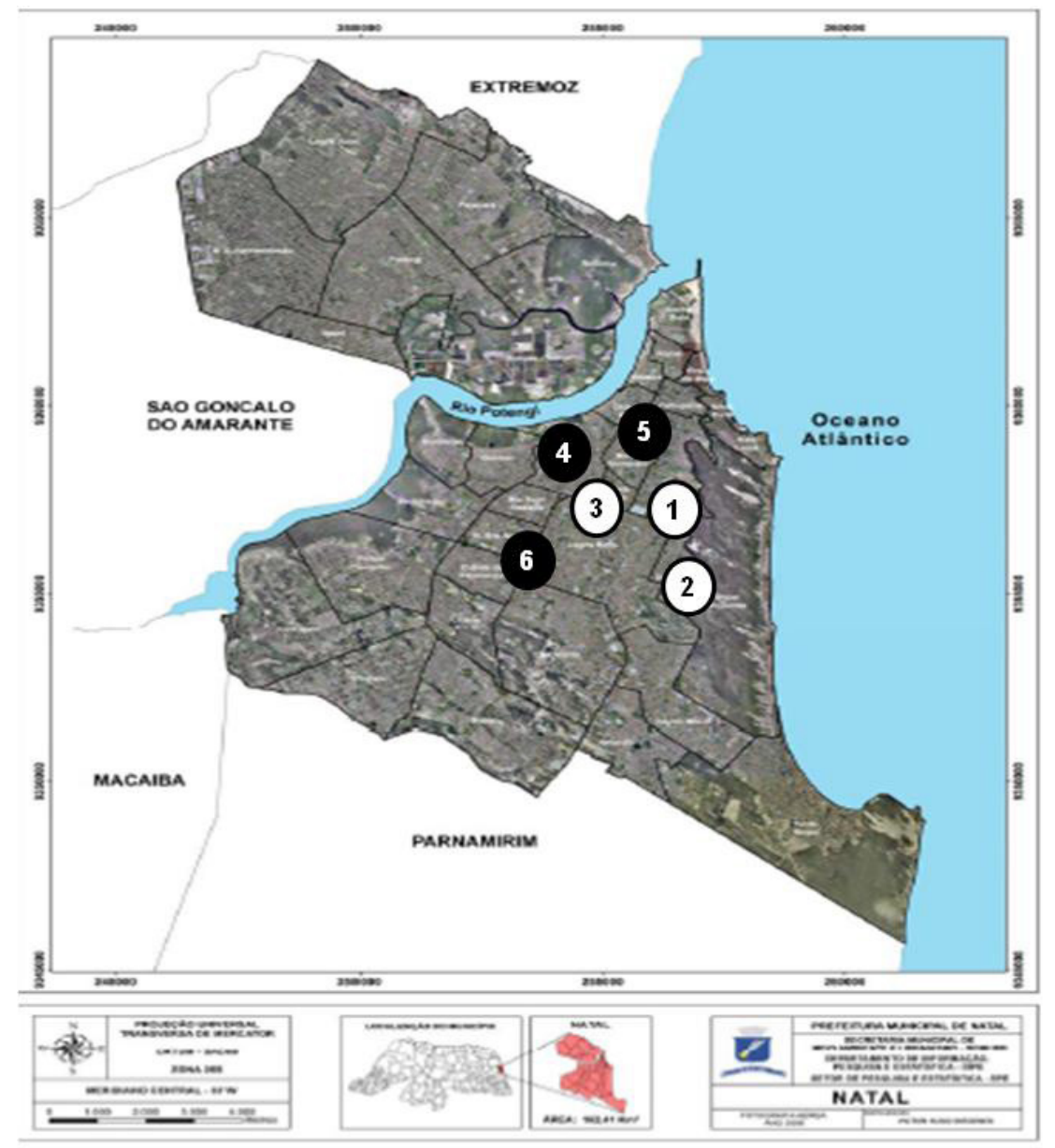

Figura 1. Localização cartográfica dos estabelecimentos comerciais destinados à compra de hortaliças, ordenados em supermercados ( 1 = S1, 2 = S2 e 3 = S3) e feiras livres (4 = F1, 5 = F2, 6 = F3) (Fonte: SEMURB-RN - site: http:// www.natal.rn.gov.br/semurb/acesso em 20/08/2012 - modificado).

a $6,6 \%$, como concentração de ácido acético variando entre 4 a $6 \%$.

Para o teste dos coliformes foi utilizado água peptonada alcalina $0,1 \%$ (HIMEDIA $®)$ e o meio Lauril Sulfato com reagente ONPG-MUG (Ortonitrofenil-ßs-D-galactopiranosideo e 4-methylumbelipheril- $\beta$-D-glucuronide) (Aquatest - Laborclin®), para a pesquisa de formas parasitárias foi utilizada uma solução de Sulfato de Zinco a 33\% e uma solução de iodo (lugol) a 0,5\%.

Após cada coleta, as amostras foram separadas por tipo, em seus respectivos sacos de origem, e transportadas com o auxilio de caixas de isopor com gelo ao Laboratório da Bacteriologia Médica (LaBMed) da Universidade Federal do Rio Grande do Norte (UFRN) e mantidas sob refrigeração com temperatura variando entre $2^{\circ} \mathrm{C}$ e $8^{\circ} \mathrm{C}$. Os materiais destinados ao processamento das hortaliças (colheres, pinceis, bacias e bancadas) foram higienizados com álcool a $70 \%$.

Em seguida, os exemplares foram agrupados em um único recipiente, fragmentados por picotamento, misturados e as partes impróprias para consumo, tais como folhas deterioradas, raízes e caules, foram desprezados. Foram, então, pesados em três grupos de $50 \mathrm{~g}$ cada e divididos em: grupo controle (amostra não higienizada - tratada unicamente com água destilada estéril), amostra para tratamento com hipoclorito de sódio a $1 \%$ e amostra para tratamento com solução de ácido acético a 6,6\%. A solução de hipoclorito de sódio foi preparada com uma proporção de $297 \mathrm{~mL}$ de água destilada estéril para 3mL de hipoclorito de sódio comercial, em uma diluição de 1:100 (1\%). A solução de lavagem com ácido acético foi preparada com uma diluição 1:15 com 280mL de água destilada estéril para $20 \mathrm{~mL}$ de solução de ácido acético comercial (6,6\%), (Figura 2).

Para a avaliação parasitológica, transferiu-se inicialmente $200 \mathrm{~mL}$ de cada amostra, recém processada, para um cálice cônico de $250 \mathrm{~mL}$ de capacidade. A amostra foi filtrada com o auxilio de um tamis preparado com 4 dobras de gaze. Em seguida, mantida em repouso por $24 \mathrm{~h} \pm 2$, para sedimentação. Decorrido esse intervalo, desprezou-se o sobrenadante, mantendo-se aproximadamente $24 \mathrm{~mL}$ em cada cálice cônico, em seguinda esse volume foi fracionado em dois tubos cônicos tipo falcon, cada um contendo $12 \mathrm{~mL}$. Após essa etapa, os conteúdos dos tubos foram centrifugados a $1015 \mathrm{~g}$, durante $5 \mathrm{mi}$ nutos, e um tubo foi usado para o método de Faust e o 


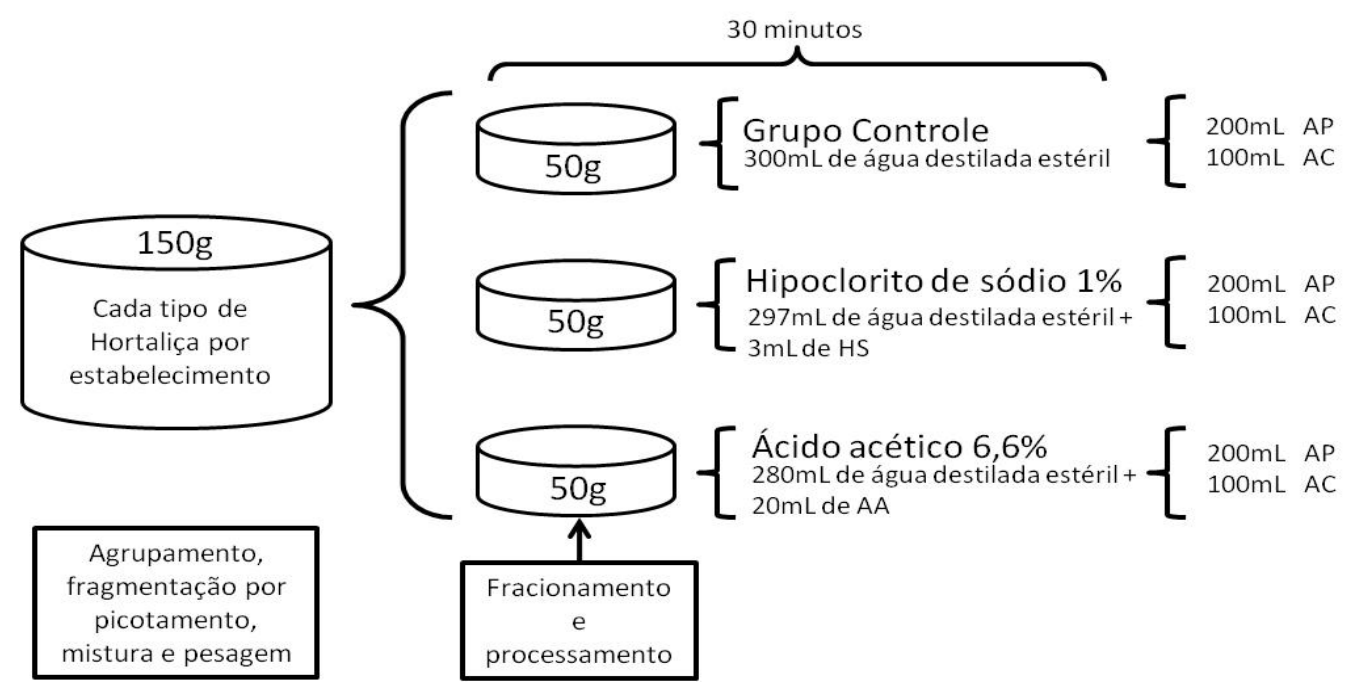

Figura 2. Esquema de processamento das amostras de hortaliças, destacando-se o grupo controle, amostras tratadas com solução de hipoclorito de sódio (HS) e amostras tratadas com solução de ácido acético (AA), para análises parasitológicas (AP) e de coliformes (AC).

outro para a o método de Hoffman, Pons e Janer (HPJ).

Para o método de Faust, após a centrifugação inicial de 5 minutos, desprezou-se o sobrenadante do tubo falcon e resuspendeu-se o precipitado com solução de sulfato de zinco a 33\%, em seguida uma nova centrifugação foi realizada com mesma rotação durante 2 minutos, observando-se a formação de uma película sobrenadante. Tanto para o método de Hoffman, Pons e Janer (HPJ), quanto para o método de Faust, pipetouse $50 \mu \mathrm{l}$ do precipitado, adicionando-o a uma lâmina, contendo igual volume de lugol a $0,5 \%$, sobrepondo-a com uma lamínula e, em seguida, procedeu-se a análise das estruturas parasitárias nas objetivas de 100x e 400x.

Para a quantificação dos grupos coliformes, transferiu-se $100 \mathrm{~mL}$, de cada tipo de amostra processada, para frascos estéreis, homogeneizando-as em vortex por aproximadamente 2 minutos. Em seguida, para a diluição do meio cromogênico Aquatest $₫$, adicionou-se uma ampola do meio em $100 \mathrm{ml}$ de água destilada estéril.

Posteriormente foi realizada a técnica do Número

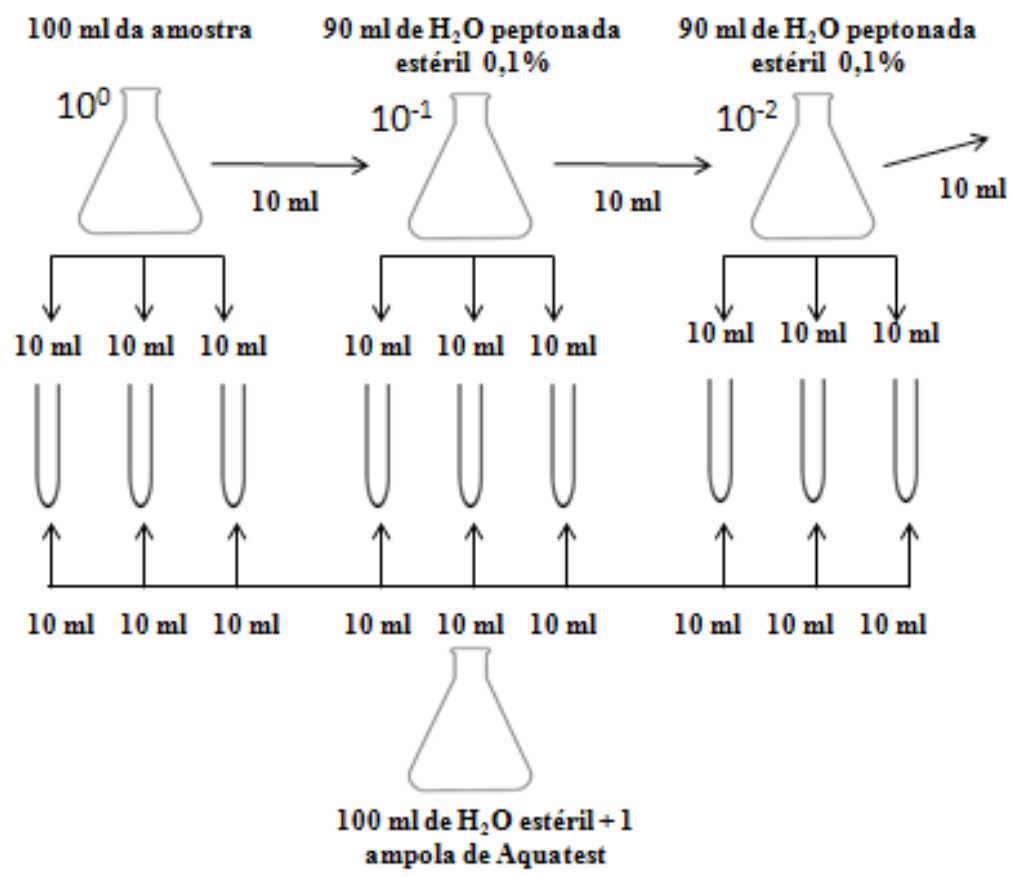

Figura 3. Esquema de processamento das amostras destinadas à avaliação de coliformes totais e coliformes termotolerantes, pela técnica do NMP. 
Mais Provável (NMP), com 9 tubos de ensaio de $20 \mathrm{ml}$ de capacidade cada, em 3 séries de diluição seriada, conforme a Figura 3. Após a distribuição das amostras e do meio Aquatest, realizou-se uma incubação dos 9 tubos a $35^{\circ} \mathrm{C} \pm 0,5^{\circ} \mathrm{C}$, durante $24 \pm 2$ horas. Decorrido o tempo de incubação, realizou-se a interpretação dos resultados de acordo com a coloração visualizada em cada tubo, da seguinte maneira: tubos que se mostravam incolores eram reportando como ausentes para a presença de coliformes totais, enquanto que tubos com a coloração amarela eram reportados como indicadores da presença de coliformes totais (Figura 6); para esses tubos procedia-se com a avaliação da presença ou ausência de coliformes termotolerantes, e aqueles que apresentavam fluorescência, quando expostos a radiação UV (365 nm), eram relatados como positivos para a presença de coliformes termotolerantes, do tipo Escherichia coli (Figura 7 ).

Após a identificação da presença ou ausência de grupos coliformes, procedeu-se a análise quantitativa do número de tubos positivos, tanto para coliformes totais quanto para coliformes termotolerantes, através do método do número mais provável (NMP), consultando-se a tabela estatística de McGrady (Anexo 01).Para a análise estatística, além da estatística descritiva, foi utilizado o test $t$ de student através do Programa SPSS ${ }^{\circ}$ Statistics
17.0, considerando um $\alpha=0,05$.

\section{Resultados}

Das 24 amostras analisadas do grupo controle, coletadas em seis diferentes tipos de estabelecimentos comerciais, constatou-se, quanto à análise de formas parasitárias, um percentual de contaminação de 41,7 $\%$ (Tabela 2).

Do total de $41,7 \%$ das amostras positivas para formas parasitárias, verificou-se a presença de oito diferentes tipos de parasitas. Em ordem crescente de prevalência, os parasitas encontrados foram cisto de Endolimax nana, 22,2\%, ovo de Toxocara ssp. e larva de Strongyloides stercoralis, 16,7\%, cada, larvas de Echinococcus granulosus e cisto de Entamoeba coli, 11,1\% para ambos os parasitas, e larva de Ancilostomideo ssp., cisto de Entamoeba histolytical dispar, ovo de Ancilostomideo ssp. e cisto de Chilomastix mesnili, cada um apresentando uma prevalência de 5,6\% (Tabela 1 e figura 4 ).

Entre as amostras de hortaliças do grupo controle, analisadas no presente estudo, que apresentaram qualidade insatisfatória para consumo, por contaminação parasitária, $30 \%$, eram provenientes dos supermercados analisados e $70 \%$ das feiras livres (tabela 2 ).

Tabela 1. Parasitas encontrados por tipo de hortaliça e tratamento higienizante.

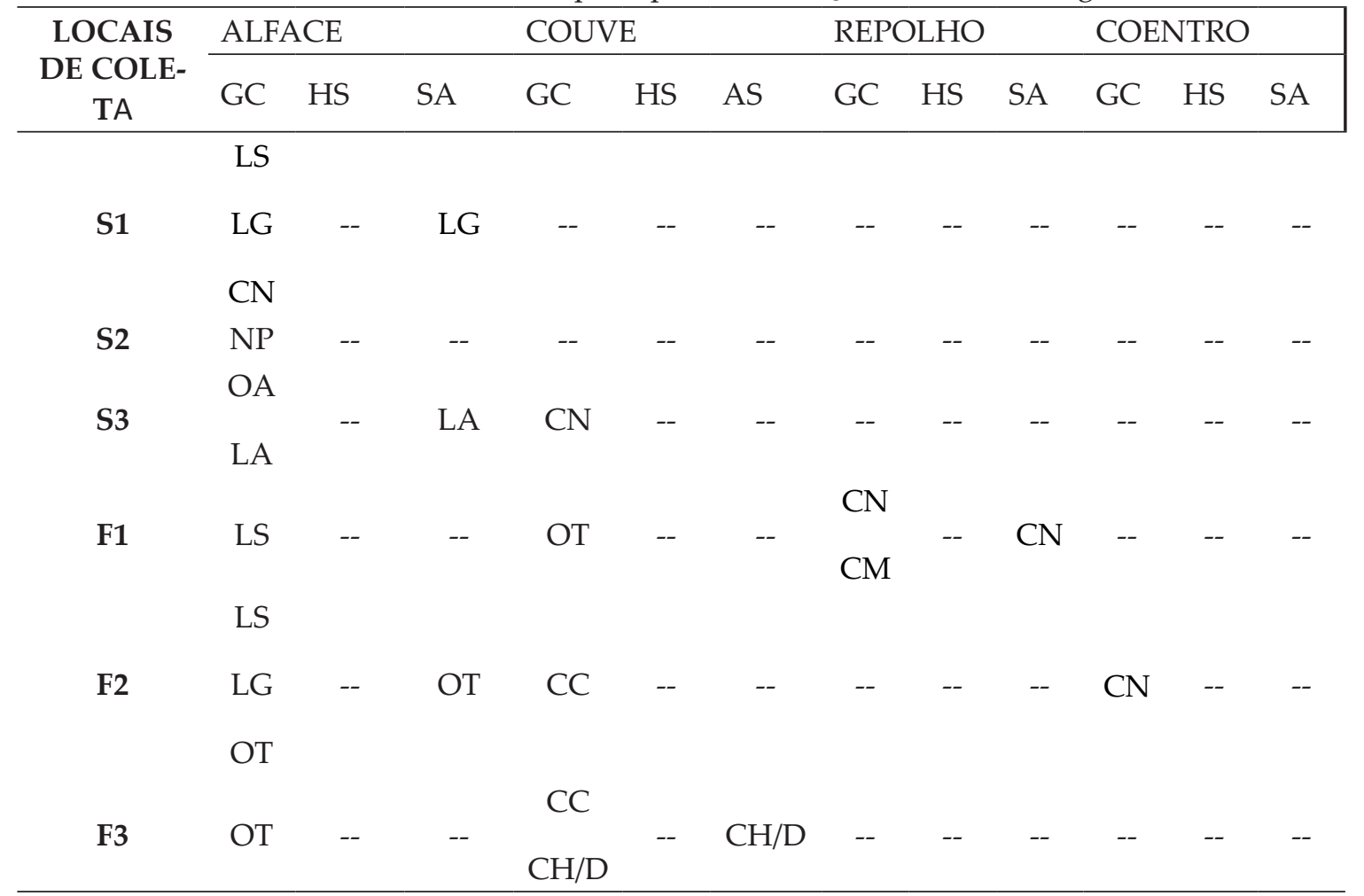

GC: Grupo Controle; HS: Amostras tratadas com solução de hipoclorito de sódio; AS: Amostras tratadas com solução de ácido acético; -- : Amostras negativas para a presença de formas parasitárias; LS: Larva de Strongyloides stercoralis; LG: Larva de Echinococcus granulosus; LA: Larva de Ancilostomideo; OA: Ovo de Ancilostomideo; OT: Ovo de Toxocara ssp.; CC: Cisto de Entamoeba coli; CH: Cisto de Entamoeba histolytical Entamoeba dispar; CM: Cisto de Chilomastix mesnili; CN: Cisto de Endolimax nana. 


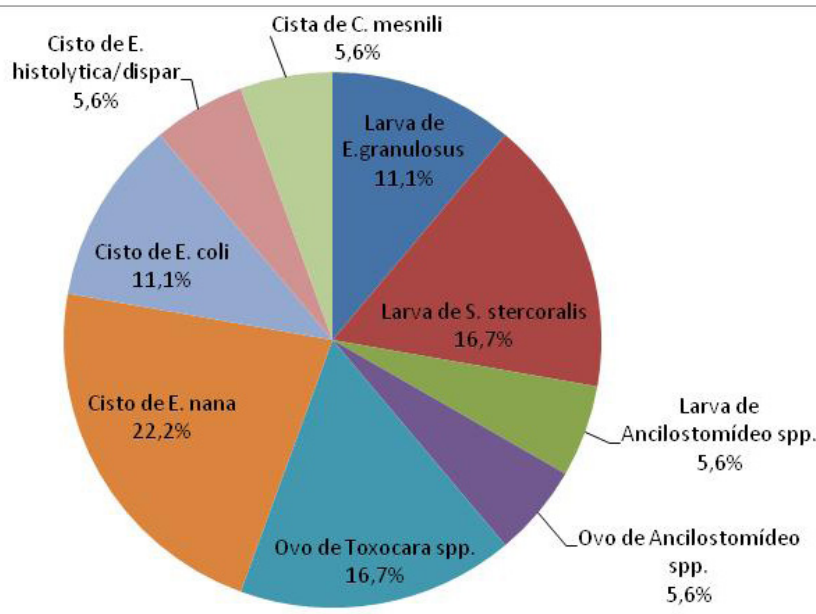

Figura 4. Percentual de parasitas encontrados entre as amostras analisadas.

Tabela 2. Distribuição de frequências e percentuais de contaminação por parasitas em hortaliças, por tipo de estabelecimento comercial e carga parasitária

\begin{tabular}{|c|c|c|c|c|c|c|c|c|}
\hline $\begin{array}{c}\text { Estabelecimentos } \\
\text { comerciais }\end{array}$ & Amostras & Total & $\begin{array}{l}\mathrm{AP} \\
(\%)\end{array}$ & $\begin{array}{l}\text { MO } \\
(\%)\end{array}$ & $\begin{array}{l}\text { MT } \\
(\%)\end{array}$ & $\begin{array}{c}\text { AP } \\
41,7 \%\end{array}$ & $\begin{array}{l}\text { MO } \\
(n=7)\end{array}$ & $\begin{array}{l}\text { MT } \\
(n=3)\end{array}$ \\
\hline \multirow{4}{*}{ Supermercados } & Alface & 3 & $\begin{array}{c}2 \\
(66,6) \\
\end{array}$ & $\begin{array}{c}1 \\
(50) \\
\end{array}$ & $\begin{array}{c}1 \\
(50 \%) \\
\end{array}$ & \multirow{4}{*}{$30 \%$} & \multirow{4}{*}{$28,6 \%$} & \multirow{4}{*}{$33,4 \%$} \\
\hline & Couve & 3 & $\begin{array}{c}1 \\
(33,3) \\
\end{array}$ & $\begin{array}{c}1 \\
(100) \\
\end{array}$ & $\begin{array}{c}0 \\
(100 \%) \\
\end{array}$ & & & \\
\hline & Repolho & 3 & $\begin{array}{c}0 \\
(100)\end{array}$ & -- & -- & & & \\
\hline & Coentro & 3 & $\begin{array}{c}0 \\
(100) \\
\end{array}$ & -- & -- & & & \\
\hline \multirow{4}{*}{ Feiras livres } & Alface & 3 & $\begin{array}{c}3 \\
(100)\end{array}$ & $\begin{array}{c}1 \\
(33,3)\end{array}$ & $\begin{array}{c}2 \\
(66,6)\end{array}$ & \multirow{4}{*}{$70 \%$} & \multirow{4}{*}{$71,4 \%$} & \multirow{4}{*}{$66,6 \%$} \\
\hline & Couve & 3 & $\begin{array}{c}2 \\
(66,6) \\
\end{array}$ & $\begin{array}{c}2 \\
(100) \\
\end{array}$ & -- & & & \\
\hline & Repolho & 3 & $\begin{array}{c}1 \\
(33,4) \\
\end{array}$ & $\begin{array}{c}1 \\
(100) \\
\end{array}$ & -- & & & \\
\hline & Coentro & 3 & $\begin{array}{c}1 \\
(33,4) \\
\end{array}$ & $\begin{array}{c}1 \\
(100) \\
\end{array}$ & -- & & & \\
\hline \multicolumn{2}{|c|}{ Total de amostras (\%) } & 24 & $\begin{array}{c}10 \\
(100 \%)\end{array}$ & $\begin{array}{c}7 \\
(100 \%) \\
\end{array}$ & $\begin{array}{c}3 \\
(100 \%) \\
\end{array}$ & $100 \%$ & $100 \%$ & $100 \%$ \\
\hline
\end{tabular}

AP: Número de amostras positivas; NA: Número de amostras negativas; MO: Número de amostras monoparasitadas; MT: Número de amostras multiparasitadas. 
A alface foi a hortaliça com maior carga parasitária, $50 \%$, seguida das amostras de couve, $30 \%$, repolho e coentro, $10 \%$ cada. O multiparasitismo foi observado em $66,6 \%$ das amostras comercializadas em feiras livres e em 33,4\% das amostras provenientes de supermercados, enquanto que a taxa de monoparasitismo foi de $28,6 \%$ para as redes de supermercados e $71,4 \%$ para as feiras livres, conforme a Tabela 2.

Os resultados observados, no presente estudo, relatam níveis semelhantes de contaminação por parasitas em hortaliças adquiridas em feiras livres e supermercados, representado pela figura 8 , e, para ambos os estabelecimentos comerciais, a probabilidade da aquisição de hortaliças contaminadas por parasitas foi a mesma $(p \leq 0,223)$.
Após o período de incubação das amostras destinadas à identificação dos grupos coliformes, constatou-se os seguintes resultados, conforme as figuras 6 e 7 .

A determinação do $\mathrm{NMP} / 100 \mathrm{ml}$ de coliformes totais e coliformes termotolerantes demonstrou que todas as amostras apresentaram níveis elevados de contaminação, considerando que $100 \%$ do grupo controle apresentou contaminação por coliformes totais e $83,3 \%$ por coliformes termotolerantes (Tabela 3).

A média global de contaminação por coliformes termotolerantes no grupo controle evidenciou que apenas um estabelecimento, dentre os seis analisados, apresentou nível de contaminação por esses microrganismos em conformidade com a RDC, conforme a tabela 3.

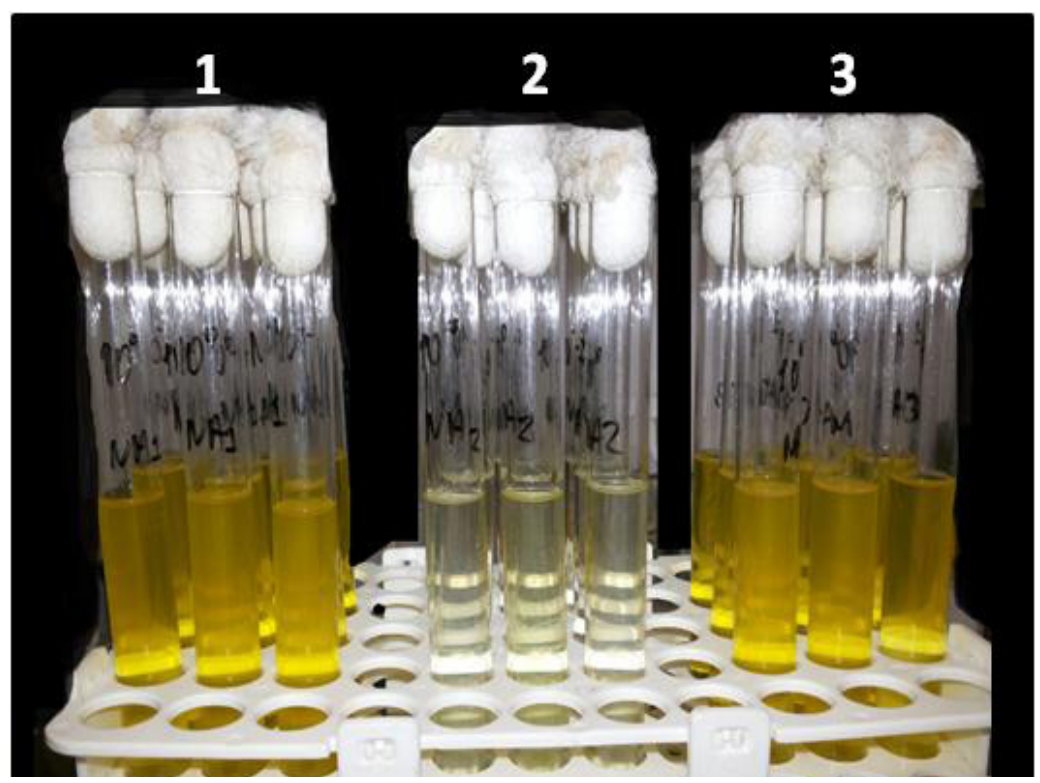

Figura 6. Disposição dos tubos seriados, após 24 horas de incubação, a coloração amarela indica crescimento de coliformes totais. Em sequência, os tubos do grupo controle (1), tubos tratados com solução de hipoclorito de sódio (2) e tubos tratados com solução de ácido acético (3).

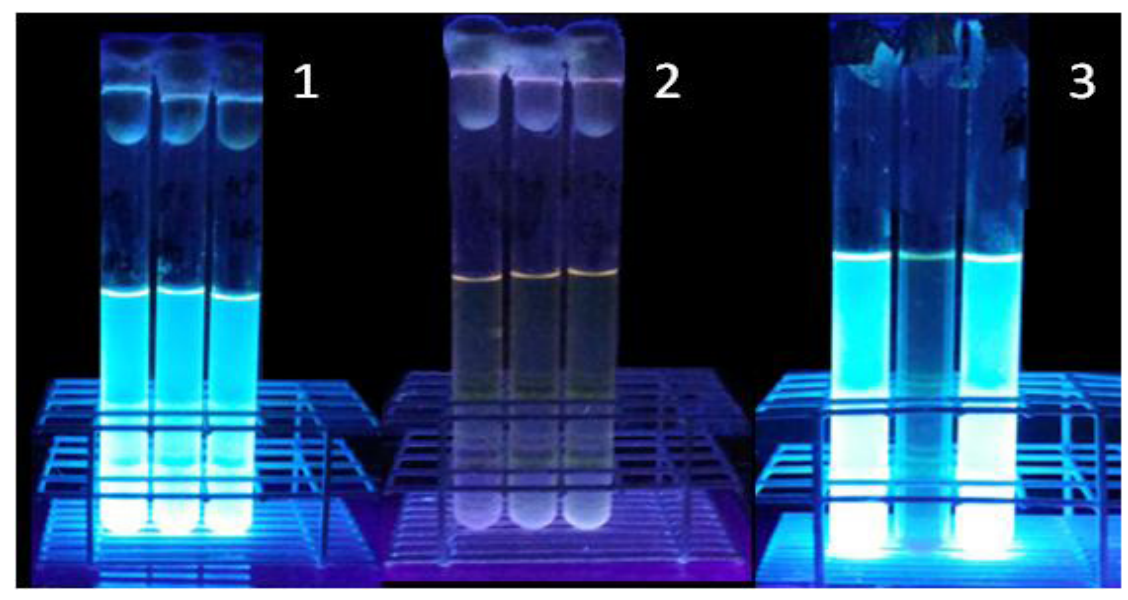

Figura 7. Tubos do NMP submetidos à luz Ultra Violeta, grupo controle (1), tratados com solução de hipoclorito de sódio (2) e tratados com solução de ácido acético (3). Em destaque a reação de fluorescência nos tubos do grupo 1 e 3 , indicando a presença de coliformes termotolerantes. 
Tabela 3. Percentual de redução da contaminação de hortaliças, segundo o tipo de agente higienizante e o estabelecimento comercial

\begin{tabular}{|c|c|c|c|c|c|c|c|c|c|}
\hline \multirow{3}{*}{ LOCAIS } & \multicolumn{3}{|c|}{ PARASITAS } & \multicolumn{3}{|c|}{ COLIFORMES } & \multicolumn{3}{|c|}{$\begin{array}{c}\text { COLIFORMES TERMOTOLERAN- } \\
\text { TES }\end{array}$} \\
\hline & GC & HS & SA & GC & HS & SA & GC & HS & SA \\
\hline & Média & EF \% & EF \% & Média & $\begin{array}{l}\text { Média } \\
(\mathrm{EF} \%)\end{array}$ & $\begin{array}{l}\text { Média } \\
\text { (EF \%) }\end{array}$ & Média & $\begin{array}{l}\text { Média } \\
(\mathrm{EF} \%)\end{array}$ & $\begin{array}{l}\text { Média } \\
\text { (EF \%) }\end{array}$ \\
\hline S1 & 4 & 100 & 50 & 1800 & $\begin{array}{c}<3 \\
(100)\end{array}$ & $\begin{array}{l}1315 \\
(27)\end{array}$ & 315 & $\begin{array}{c}<3 \\
(100)\end{array}$ & $\begin{array}{c}<3 \\
(100)\end{array}$ \\
\hline S2 & 1 & -- & -- & 1494 & $\begin{array}{c}<3 \\
(100)\end{array}$ & $\begin{array}{l}1093 \\
(2,5)\end{array}$ & 322 & $\begin{array}{c}<3 \\
(100)\end{array}$ & $\begin{array}{c}107 \\
(66,8)\end{array}$ \\
\hline S3 & 2 & 100 & 50 & $>2400$ & $\begin{array}{c}12 \\
(99,5)\end{array}$ & $\begin{array}{c}>2400 \\
(0)\end{array}$ & 1475 & $\begin{array}{c}<3 \\
(100)\end{array}$ & $\begin{array}{l}1150 \\
(22)\end{array}$ \\
\hline F1 & 1,6 & 100 & 60 & $>2400$ & $\begin{array}{c}602 \\
(74,9)\end{array}$ & $\begin{array}{c}1806 \\
(0)\end{array}$ & $32^{*}$ & $\begin{array}{c}<3 \\
(100)\end{array}$ & $\begin{array}{c}11 \\
(65,8)\end{array}$ \\
\hline F2 & 2 & 100 & 66,6 & $>2400$ & $\begin{array}{c}604 \\
(74,8)\end{array}$ & $\begin{array}{c}>2400 \\
(0)\end{array}$ & 1271 & $\begin{array}{c}6 \\
(99,5)\end{array}$ & $\begin{array}{c}627 \\
(50,6)\end{array}$ \\
\hline F3 & 2 & 100 & 50 & 2075 & $\begin{array}{c}<3 \\
(100)\end{array}$ & $\begin{array}{l}1535 \\
(36)\end{array}$ & 511 & $\begin{array}{c}<3 \\
(100)\end{array}$ & $\begin{array}{c}364 \\
(28,8)\end{array}$ \\
\hline
\end{tabular}

GC: Grupo controle; HS- Amostras tratadas com solução de hipoclorito de sódio; SA- Amostras tratadas com solução de ácido acético; EF: porcentagem da eficiência de redução antimicrobiana. *: Nível aceitável conforme a RDC no 12 da ANVISA de 2001.

A análise dos grupos coliformes demonstrou que a alface foi considerada a hortaliça com maiores médias de contaminação por coliformes totais e coliformes termotolerantes, apresentando valores acima de 2400 $\mathrm{NMP} / 100 \mathrm{~mL}$ e $1356 \mathrm{NMP} / 100 \mathrm{~mL}$, respectivamente. O repolho foi a hortaliça menos contaminada, com médias de contaminação de $1613 \mathrm{NMP} / 100 \mathrm{~mL}$ para coliformes totais e $13 \mathrm{NMP} / 100 \mathrm{~mL}$ para coliforme termotolerantes
(Tabela 4).

Após a análise da contaminação do grupo controle por coliformes totais, observou-se que $100 \%$ dessas amostras estavam contaminadas. Enquanto que o teste para coliformes termotolerantes mostrou um percentual de 83,3\% de contaminação nas amostras testadas (Tabela 3).

Os resultados observados nesse trabalho mostram que não há diferenças na aquisição de hortaliças contamina-

Tabela 4. Concentração média dos grupos coliformes de acordo com o método de higienizante e o tipo de hortaliça - NMP/100mL.

\begin{tabular}{ccccccc}
\hline \multirow{2}{*}{ Locais } & \multicolumn{3}{c}{ Coliformes totais } & \multicolumn{3}{c}{ Coliformes termotolerantes } \\
\cline { 2 - 7 } & GC & HS & SA & GC & HS & SA \\
\hline Alface & $>2400$ & $<3$ & $>2400$ & 1356 & $<3$ & 1028 \\
Couve & $>2400$ & 3 & 1860 & 680 & $<3$ & 241 \\
Repolho & 1613 & 800 & 1396 & 13 & 4 & 11 \\
Coentro & 1967 & 9 & 1320 & 567 & $<3$ & 228 \\
\hline
\end{tabular}

GC: Amostras do grupo controle; HS: Amostras tratadas com solução de hipoclorito de sódio; SA: Amostras tratadas com solução de ácido acético. 
das por coliformes totais $(\mathrm{p} \leq 0,193)$ ou termotolerantes $(p \leq 0,789)$, em supermercados ou feiras livres (Figura 8).

De um total de $41,7 \%$ das amostras do grupo controle, que apresentaram alguma forma de contaminação proveniente de fontes parasitárias, todas foram submetidas ao tratamento com solução de hipoclorito de sódio a $1 \%$ e solução de ácido acético a 6,6\%. Em 100\% das amostras contaminadas, submetidas à solução de hipoclorito de sódio, houve uma redução do número de parasitas, ao passo que as amostras submetidas ao

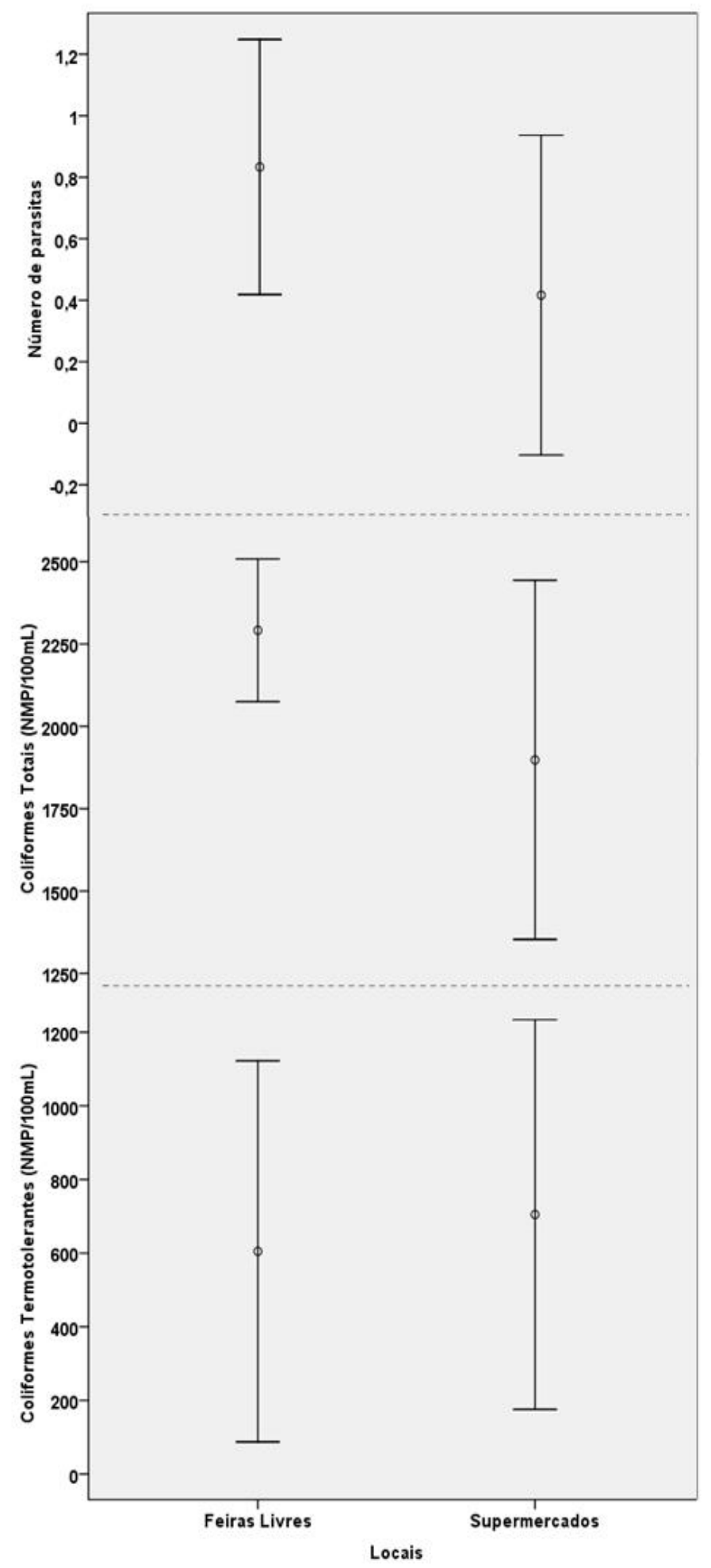

Figura 8. Valores médios do número de parasitas e do número mais provável de coliformes totais e coliformes termotolerantes por tipo de estabelecimento comercial, com intervalo de confiança de $95 \%$. 
tratamento com solução de ácido acético a 6,6\% tiveram redução média do número de formas parasitárias de $71 \%$ (Tabela 3 ).

Estabelecendo-se um comparativo de contaminação parasitária, de acordo com o tipo de agente sanitizante, constatou-se que a solução de hipoclorito de sódio a 1\% e a solução de ácido acético a 6,6\% apresentaram ação antiparasitária similares com $\mathrm{p} \leq 0,001$ e $\mathrm{p} \leq 0,004$, respectivamente (Figura 9), evidenciando-se uma discreta eficiência da solução de hipoclorito de sódio em relação

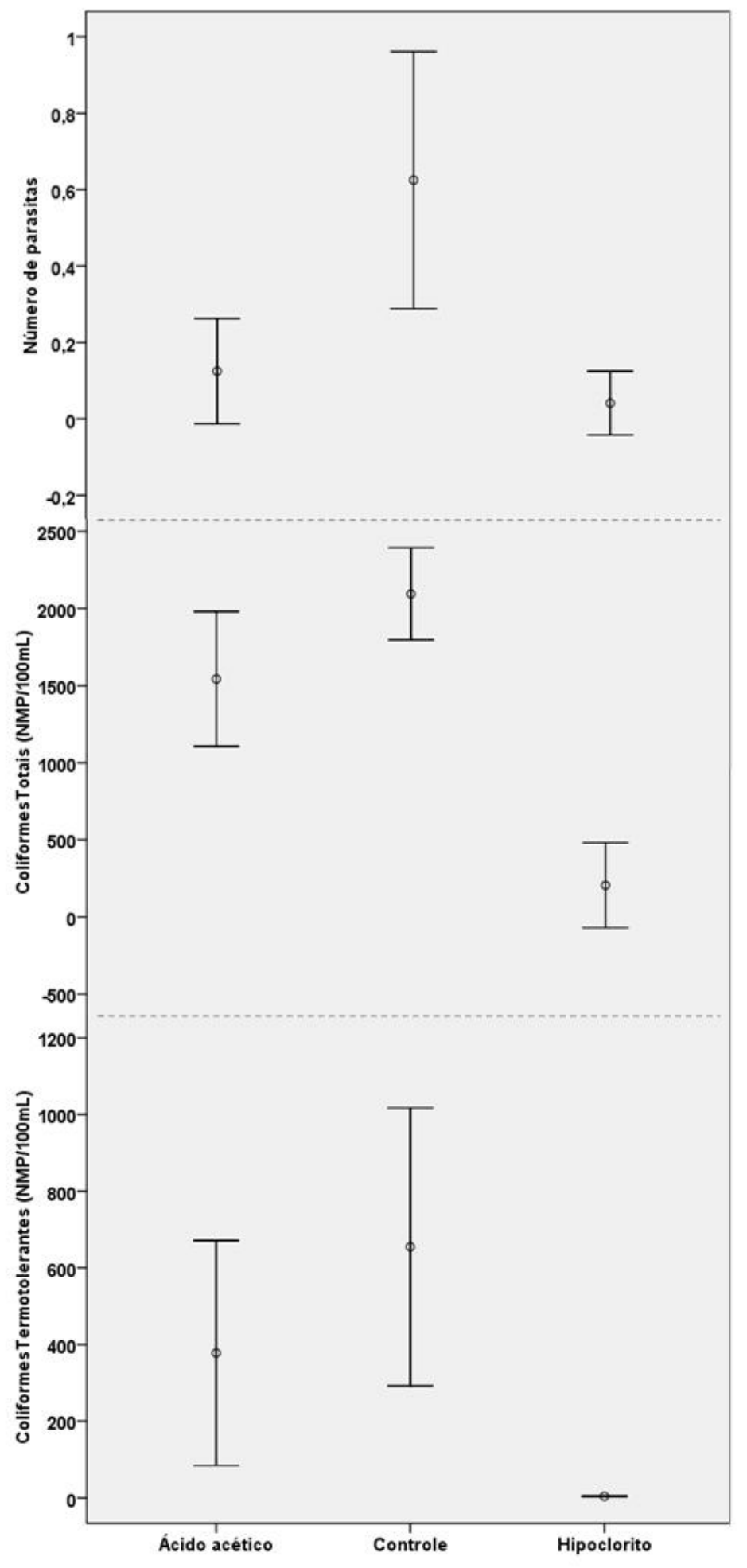

Figura 9. Valores médios do número de parasitas e do número mais provável de coliformes totais e coliformes termotolerantes, segundo o tipo de agente higienizante, com intervalo de confiança de 95\%. 
à solução de ácido acético.

A determinação do NMP/100mL de coliformes totais e termotolerantes em amostras tratadas com agentes higienizantes apontou que todas as amostras tratadas com solução de acido acético a 6,6\% mantiveram níveis elevados de contaminação por coliformes totais, enquanto que para coliformes termotolerantes apenas $50 \%$ dos estabelecimentos analisados apresentaram média global de contaminação aceitável, conforme a legislação brasileira (Tabela 3). Avaliando-se a eficiência média de ambas as soluções higienizantes, constatou-se que o hipoclorito de sódio a $1 \%$ e o ácido acético a 6,6\% apresentaram uma eficiência média para coliformes totais de $91,5 \%$ e $15,9 \%$, respectivamente, enquanto que para coliformes termotolerantes essa eficiência foi de $99,9 \%$ para o hipoclorito de sódio e de $55,7 \%$ para o ácido acético, conforme a tabela 3.

Avaliando-se a eficácia da ação dos agentes higienizantes, constatou-se, nesse estudo, que $100 \%$ das amostras tratadas com solução de hipoclorito de sódio a $1 \%$ apresentaram níveis aceitáveis de contaminação por coliformes termotolerantes para consumo humano, conforme a RDC n ${ }^{\circ} 12$ de 2001 da ANVISA e, dentre os 6 estabelecimentos analisados, apenas 2 apresentaram contaminação por coliformes totais após o tratamento com hipoclorito de sódio.

A análise estatística para coliformes totais revelou uma eficiência antimicrobiana de ambas as soluções, no entanto, a solução de hipoclorito de sódio a $1 \%$ mostrou-se mais eficiente $(p \leq 0,001)$ em relação à solução de ácido acético a $6,6 \%(p \leq 0,02)$. Na análise dos coliformes termotolerantes, ficou claro que a solução de hipoclorito de sódio a $1 \%$ foi bem mais eficiente $(p \leq 0,000)$, quando comparada à solução de ácido acético $(p \leq 0,0059)$ (Figura 9).

\section{Discussão}

A percentagem de contaminação por parasitas constatada nesse trabalho foi diferente de um estudo anterior realizado na cidade do Rio Janeiro, que relatou uma prevalência de $21,4 \%$ para o mesmo tipo de análise em hortaliças comercializadas (SILVA et al., 1995). Em outro trabalho semelhante, realizado no Município de Lajes, na cidade de Santa Catarina, foram observados índices de contaminação parasitária, em feiras livres e supermercados, superiores aos valores encontrados nesse estudo (88,5\%), e segundo os autores, o emprego de práticas inadequadas de irrigação, coleta, transporte, armazenamento e comercialização dessas hortaliças associam-se ao alto índice de contaminação relatado (QUADROS et al., 2008).

De acordo com a resolução nำ12 de 1978 da ANVISA, uma hortaliça é considerada própria para consumo humano quando apresenta ausência de sujidades e formas parasitárias (BRASIL, 1978).
Cantos e colaboradores (2004), ao analisarem a prevalência de estruturas parasitárias em hortaliças comercializadas em Florianópolis-SC, constataram elevado índice de contaminação por larvas de Strongyloides stercoralis, ovos de Ancilostomídeos, cistos de Entamoeba coli e cistos de Entamoeba histolytica/Entamoeba díspar.

Gontijo (2012), ao analisar o perfil de contaminação parasitológica em hortaliças comercializadas em feiras e supermercados localizados no município de Gurupi - TO, constatou que $60 \%$ das amostras estavam contaminadas por parasitas e que a E. nana apresentava uma prevalência de $21,82 \%$, resultado semelhante ao deste estudo.

Apesar da E. nana não ser considerada uma espécie patogênica, sua prevalência nesse estudo pode indicar uma possível contaminação das amostras de hortaliças por água e dejetos fecais de origem humana (NOLLA e CANTOS, 2005).

A ocorrência de ovos de Toxocara ssp., bem como larvas de E. granulosus, nesse estudo, indica um possível contato das hortaliças analisadas com água de irrigação contaminada pelo contato direto com cães e gatos ou seus dejetos, uma vez que esses animais são considerados os principais hospedeiros desses parasitas. A toxocaríase pode acarretar, no homem, manifestações da larva migrans visceral, incluindo graves complicações pulmonares, oculares e neurológicas. O E. granulosus consiste em uma tênia encontrada somente no intestino de cães e outros canídeos. Os ovos deixam esses hospedeiros e infectam animais de pasto, as larvas eclodem dos ovos penetram no intestino e migram para diversos tecidos, tais como fígado, baço, músculo e cérebro. Os seres humanos são considerados intermediários e não hospedeiros definitivos desses parasitas (MACKENZIE et al., 1995).

A contaminação pelos geo-helmintos, Strongyloides stercoralis, Ancilostomideo ssp. e Echinococcus granulosus, nas hortaliças analisadas nesse estudo, sugere a ocorrência de práticas higiênico sanitárias inadequadas nos locais de cultivo dessas amostras, uma vez que esses parasitas necessitam, obrigatoriamente, do solo para completar o seu ciclo de vida (ROCHA et al., 2008).

A presença de larvas de Strongyloides stercoralis, nesse estudo, também foi relatada em outro trabalho realizado por Rocha e coloboradores (2008), na cidade de Recife - PE, no qual as amostras analisadas em supermercados e feiras livres apresentavam contaminação por esse parasita.

Parasitas do gênero Entamoeba, observados nesse estudo, sugerem uma possível contaminação associada a práticas inadequadas de irrigação, realizadas muitas vezes com água servida ou proveniente de fontes contaminadas, visto que a Entamoeba ssp. é considerada um enteroparasita de veiculação hídrica (FALAVIGNA et. al, 2005).

Embora a Entamoeba coli seja considerado um organismo comensal, não patogênico, os índices de contaminação observados nesse estudo sugerem a contaminação 
por fezes de origem humana, visto que esse parasita é considerado um protozoário intestinal humano, podendo ter sido oriundo de falhas na higienização ou nos processos de manipulação dessas amostras (SANTOS, 2009).

A contaminação fecal, da terra ou da água, consiste em um importante fator para a disseminação de parasitoses intestinais, principalmente nas regiões onde há carência de serviços sanitários e os dejetos fecais são lançados sob o solo, o que possibilita o desenvolvimento e disseminação das formas parasitárias eliminadas nas fezes. Além disso, o uso de esterco animal sem tratamento, a livre circulação de animais pelas plantações e a irrigação feita através de cursos d'água contaminados são fatores que influenciam, negativamente, a qualidade das hortaliças (NOLLA e CANTOS, 2005).

A Entamoeba histolytica é a única espécie de ameba potencialmente patogênica e, nesse estudo, apresentou uma prevalência de 5,6\%, sendo referida como E. histolytica/dispar, já que a diferenciação entre as duas espécies somente pode ser realizada através do perfil eletroforético das isoenzimas da via glicolítica dessas (REZENDE; COSTA-CRUZ; GENNARI-CARDOSO, 1997).

A baixa prevalência de contaminação por cistos de Chilomastix mesnili, relatada neste estudo, corrobora com Oliveira e Germano (1992), que, ao pesquisarem a prevalência de protozoários intestinais em amostras de hortaliças provenientes da região metropolitana do estado de São Paulo, relataram um percentual de contaminação, por esse parasita, de $4 \%$. Segundo os autores, embora não patogênico, esse parasita apresenta grande importância como indicador de contaminação fecal de origem humana.

Os índices de contaminação por coliformes, descrito nesse estudo, corroboram com o estudo realizado por Oliveira (2006), na cidade de Belém - PA, no qual todas as amostras de hortaliças analisadas apresentaram valores máximos de contaminação por coliformes totais e termotolerantes. Cabrini (2002), em um estudo realizado na cidade de Limeira, São Paulo, também relatou uma elevada contaminação de hortaliças por coliformes totais (98\%). Considerando que a legislação brasileira não possui um padrão estimado do nível aceitável de contaminação de hortaliças por coliformes totais, a avaliação da presença de coliformes totais nessas amostras foram realizadas com o intuito de estimar o número desses microrganismos e, consequentemente, obter-se o conhecimento da qualidade higiênico sanitária desses alimentos.

Silva e colaboradores (2005) e Santana e colaboradores (2006) afirmam que a presença de coliformes totais em alimentos não é considerada um indicador eficiente de contaminação, quando comparada à presença de grupos coliformes termotolerantes, uma vez que os coliformes totais podem ser provenientes de diferentes sítios, e dentre eles destacam-se a decomposição de matéria orgânica, do solo, de plantas ou, ainda, da presença de fezes humanas ou de outros organismos.
Takayanagui e colaboradores (2006) afirmam que a contaminação de hortaliças ocorre, de um modo geral, na horta, por meio da utilização de água de irrigação ou adubos contaminados, além da manipulação inadequada nos pontos de venda e transporte desses produtos.

A contagem média de coliformes totais, nesse estudo, de 2,1 x $103 \mathrm{NMP} / 100 \mathrm{~mL}$, mostrou-se abaixo do observado por Marques e colaboradores (2002), que, ao analisarem amostras de alfaces comercializadas em feiras livres, constataram que a média global de contaminação por coliformes totais foi equivalente a 2,4 x $104 \mathrm{NMP} / 100 \mathrm{~mL}$. A contagem média global de coliformes termotolerantes, no grupo controle, equivalente a 6,54 x $102 \mathrm{NMP} / 100 \mathrm{~mL}$, também discorda do estudo realizado por Guimarães e colaboradores (2003), no qual constatou-se que amostras de alface, coletadas em supermercados, apresentavam contagem média global de coliformes fecais igual a 3,2x103 NMP/100mL. Segundo RDC no 12 da AVISA (2001), o limite máximo de contaminação por coliformes termotolerantes em hortaliças é de 2 x 102 NMP/100mL.

Os níveis de contaminação constatados em feiras livres, nesse estudo, podem ser justificados pela inadequação das condições higiênico-sanitárias, observadas nesses locais, decorrentes do acondicionamento, manipulação e transporte inadequados dos alimentos, conforme afirma Barros e colaboradores (1999). Ao passo que a contaminação constatada nas redes de supermercado sugere a ausência de realização de práticas de sanitização, anteriores à distribuição desses alimentos aos estabelecimentos comerciais (CANTOS et al., 2004), ou, ainda, uma carência na qualidade higiênico-sanitária durante o cultivo dessas amostras (CARVALHO et al., 2003)

Santos e colaboradores (2010), ao avaliarem a qualidade sanitária de amostras de hortaliças higienizadas, verificaram que o grupo controle apresentou elevado índice de contaminação por grupos coliformes, com resultados semelhantes àqueles encontrados neste estudo, além disso, os autores constataram que a alface foi a hortaliça com maior incidência de contaminação por coliformes termotolerantes.

Apesar da limitada capacidade antimicrobiana do ácido acético a 6,6\%,observada nesse trabalho, outros estudos realizados mostram que a utilização dessa solução foi aquela com melhor resultado para redução de coliformes totais, coliformes termotolerantes e Vibrio cholerae, quando comparado às soluções de hipoclorito de sódio a $1 \%$, ácido acético a 0,2\% e 0,3\% e uma combinação de hipoclorito de sódio com vinagre (SANTOS, 2004).

As diferenças entre os níveis de contaminação dos trabalhos podem estar associadas, fundamentalmente, às condiçõos sanitárias do ambiente em que essas amostras são cultivadas, os quais são diferentes em cada sistema produtor, de acordo com as práticas de cultivo utilizadas e a sociedade na qual encontram-se inseridas (QUADROS et al., 2008).

Segundo Santana e colaboradores (2006), quanto maior 
a contaminação inicial do produto, menor a eficiência do processo de sanitização. Além disso, a fisiologia de alguns microorganismos, associada a mecanismos de resistência, podem afetar decisivamente a ação antimicrobiana dos agentes sanitizantes (FDA, 2001), isso pode justificar a ocorrência de coliformes totais em amostras tratadas com hipoclorito de sódio, verificada nos estabelecimentos F1 e F2, conforme a tabela 3 .

De acordo com um estudo realizado em Pelotas RS, onde foi avaliada a eficácia de diferentes métodos antimicrobianos na alface, para redução de coliformes totais e coliformes termotolerantes, utilizando lavagem com água, água e vinagre, água e hipoclorito de sódio, o que se mostrou mais eficaz foi o hipoclorito de sódio (SANTOS, 2004). Oliveira (2005), ao analisar os métodos de higienização de vegetais empregados em restaurantes de Porto Alegre - RS, após os tratamentos com hipoclorito de sódio, durante 30 minutos, verificou que houve um decréscimo nas contagens de coliformes termotolerantes, em relação à população inicial das amostras de alface analisadas, comprovando a eficácia desse método sanitizante. Nascimento e colaboradores (2002) e Lund e colaboradores (2005) também observaram que o hipoclorito obteve melhor resultado como sanitizante, e que a higienização com o ácido acético não apresentou resultados satisfatórios.

Este estudo demonstrou a baixa qualidade higiênico-sanitária de hortaliças comercializadas na cidade de Natal - RN, tornando-se necessária uma melhor orientação aos manipuladores quanto à importância da correta higienização, minimizando, dessa forma, a transmissão de doenças de origem bacterianas e parasitárias, veiculadas por alimentos.

\section{Conclusão}

Após a análise dos resultados, conclui-se que as hortaliças podem ser grandes reservatórios de parasitas patogênicos e grupos coliformes, fazendo-se necessária a realização de medidas preventivas direcionadas à qualidade higiênico-sanitária, durante todas as etapas de produção das hortaliças, cultivo, transporte, acondicionamento, distribuição e comercialização, bem como a correta desinfecção desses alimentos.

\section{Agradecimentos}

A Universidade Federal do Rio Grande do Norte - UFRN pelo apoio logístico e a cessão da bolsa de iniciação científica.

\section{Referências}

ANTONIOLLI, L. R. et al. Efeito do hipoclorito de sódio sobre a microbiota de abacaxi "pérola" minimamente processado. Rev. Bras. Frutic., Jaboticabal - SP, v. 27, p. 157-160, 2005.

ANTUNES, M. A. Contaminação, crescimento e inativação de microrganismos na cadeia de produção de alface (Lactuca sativa L.) variedade vitória de Santo Antão. 2009. 176f. Tese (Doctor Scientiae) - Universidade Federal de Viçosa, MG, 2009.

ANVISA. Portaria CVS-6/99, de 10.03.99. Legislação em alimentação e nutrição. Regulamento técnico sobre os parâmetros e critérios para o controle higiênico-sanitário em estabelecimentos de alimentos, 1998.

AZEVEDO, E. DE. Reflexões sobre riscos e o papel da ciência na construção do conceito de alimentação saudável. Revista de Nutrição, v. 21, n. 6, p. 717723, dez. 2008.

\section{BARROS, A. J. M. et al. GESTÃO E CONTROLE} AMBIENTAL: Avaliação sanitária de hortaliças no agreste e brejo paraibanos. Revista Brasileira de Engenharia Agricola e Ambiental, v. 3, n. 083, p. 355-360, 1999.

BRASIL. Agência Nacional de Vigilância Sanitária - ANVISA. Resolução - CNNPA no 12, de 1978. Ministério da Saúde, 1978.

CABRINI, K. T. et al. Pesquisa de coliformes totais e Escherichia coli em alfaces (Lactuca sativa) comercializadas na cidade de Limeira, São Paulo, Brasil. Revista Higiene Alimentar, São Paulo, v. 16, n. 95, p. 92-94, 2002.

CANTOS, G. A. et al. Estruturas Parasitárias Encontradas em Hortaliças Comercializadas em Florianópolis, Santa Catarina. NewLab, v. 66, 2004.

COUTINHO, E. P. S. et al. Condições de higiene das feiras livres dos município de bananeiras, Solânea e Guarabira, Paraíba. X Encontro de Extensão da Universidade Federal da Paraíba, Departamento de Tecnologia Rural/ Probex, 2008.

FALAVIGNA, L. M., et al. Qualidade de hortaliças comercializadas no noroeste do Paraná, Brasil. Parasitol Latinoam, v. 60, n. 44, p. 144-149, 2005.

FONTES, G. et al. Influência do tratamento específico na prevalência de enteroparasitoses 
e esquistossomose mansônica em escolares do município de Barra de Santo Antônio. Revista da Sociedade Brasileira de Medicina Tropical, v. 36, n. 5, p. 625-628, 2003.

FREITAS, A. A. DE et al. Avaliação parasitológica de alfaces ( Lactuca sativa ) comercializadas em feiras livres e supermercados do município de Campo Mourão, Estado do Paraná. Maringá, v. 26, n. 4, p. 381-384, 2004.

GONTIJO, M. Avaliação parasitológica de alfaces (Lactuca sativa) comercializada em supermercados e feiras livres do município de Gurupi, Tocantins. Revista Cientifica do ITPAC, Araguaína, v. 5, n. 4, p. 1-10, 2012.

GUIMARÃES, A. M.; GABELLINI, E.; ALVES, L. Freqüência de enteroparasitas em amostras de alface ( Lactuca sativa ) comercializadas em Lavras , Minas Gerais. Revista da Sociedade Brasileira de Medicina Tropical, v. 36, n. 5, p. 621-623, 2003.

LUND, D. G.; PETRINI, L. A.; ROMBALDI, C. V. Uso de sanitizantes na redução da carga microbiana de mandioca minimamente processada. Ciência rural, Santa Maria, v. 35, n. 6, p. 1431-1435, 2005.

MACKENZIE, W. R., et al. Massive Outbreak of Waterborne Cryptosporidium Infection in Milwaukee, Wisconsin: Recurrence of Illness and Risk of Secondary Transmission. Clinical Infections Diseases, p. 57-62, 1995.

MARQUES, M.A.; SILVA, S.M.; MARTINS, L.P.; SANTOS, J. G. Qualidade física e microbiológica de hortaliças co- mercializadas na feira livre do município de bananeiras (PB). In: Congresso Brasileiro de Ciência e Tecnologia de Alimentos. Resumos. Porto Alegre, Sociedade Brasileira de Ciência e Tecnologia de Alimentos, p. 125, 2002.

NASCIMENTO, A. R. et al. Sanitização de saladas in natura oferecidas em restaurantes self-service de São Luis, MA. Revista Higiene Alimentar, São Paulo, v. 16, n. 92, p. 63-67, 2002.

NASCIMENTO, M. S.; CATANOZI, M. P. M.; SILVA, N. A. Avaliação microbiológica de frutas e hortaliças frescas comercializadas no município de Campinas, S. Revista Higiene Alimentar, São Paulo, v. 17, n. 114-115, p. 73-76, 2003.

NASCIMENTO, M. S.; SILVA, N.; CATANOZI, M. P. L. M. Emprego de sanitizantes na desinfecção de vegetais. Revista Higiene Alimentar, São Paulo, v. 12, n. 111, p. 42-47, 2003.
NÓBREGA, M. F. F. Perfil sócio-demográfico dos vendedores de hortaliças e prevalência de enteroparasitas humanos em Lactuva sativa L (Alface). Dissertação (Mestrado) - Universidade Estadual da Paraíba - UEPB/PRODEMA, Campina Grande - PB, 2002.

NOLLA, A. C.; CANTOS, G. A. Relação entre a ocorrência de enteroparasitoses em manipuladores de alimentos e aspectos epidemiológicos em Florianópolis, Santa Catarina, Brasil Relationship between intestinal parasites in food handlers and epidemiological factors in the city of Flori. Cad. Saúde pública, Rio de Janeiro, v. 21, n. 2, p. 641645, 2005.

OLIVEIRA, A. B. A. Comparação de diferentes protocolos de higienização de alface (Lactuca sativa) utilizada em restaurantes de Porto Alegre - RS. 2005. 58 f. Dissertação (Mestrado em Microbiologia Agrícola e do Ambiente) - Faculdade de Agronomia. Universidade Federal do Rio Grande do Sul. Porto Alegre, RS, 2005.

OLIVEIRA, C. A. F. DE; GERMANO, P. M. L. Estudo da ocorrência de enteroparasitas em hortaliças comercializadas na região metropolitana de São Paulo - SP , Brasil . II - Pesquisa de protozoários intestinais * Study of the occurrence of intestinal parasites os vegetables comercially traded in the. Revista saúde pública, São Paulo, v. 26, n. 5, p. 332-5, 1992.

OLIVEIRA, M. DE L. S. et al. Análise microbiológica de alface (Lactuta sativa, L) Maria de Lourdes Soares et al. Análise microbiológica de alface (Lactuta sativa, L.) e tomate (Solanum lycopersicum, L.), comercializados em feiraslivres da cidade de Belém, Pará. Revista Higiene Alimentar, São Paulo, v. 20, n. 143, p. 96-101, 2006.

PARTELI, D. P.; GONÇALVES, S. A. 2005. Pesquisa de parasitas intestinais em folhas de alfaces (Lactuca sativa L) comercializadas no munícipio de Vitória, ES. 2005. 31f. Dissertação (Bacharel em Farmácia) Faculdade Brasileira UNIVIX, Vitória, ES, 2005.

QUADROS, R. M. DE et al. Parasitos em alfaces ( Lactuca sativa ) de mercados e feiras livres de Lages - Santa Catarina Lettuces ( Lactuca sativa ) parasites in markets and free fairs. Revista Ciência e Saúde, Porto Alegre, v. 1, n. 2, p. 78-84, 2008.

REZENDE, C. H. A. DE; COSTA-CRUZ, J. M.; GENNARI-CARDOSO, M. L. Enteroparasitoses em manipuladores de alimentos de escolas públicas em Uberlândia ( Minas Gerais ), Brasil. Rev Panam 
Salud Publica/Pan Am J Public Health, v. 2, n. 6, p. 392-397, 1997.

ROCHA, A.; MENDES, R. D. A.; BARBOSA, C. S. Strongyloides ssp. E OUTROS PARASITAS ENCONTRADOS EM ALFACES ( Lactuca sativa ). Revista patologia tropical, v. 37, n. 2, p. 151-160, 2008.

RODRIGUES, D. M. S. Perfil higiênco-sanitário de feiras livres do Distrito Federal e avaliação da satisfação da seus consumidores. Dissertação (especialização em qualidade de alimentos) Centro de Excelência em Turismo, Universidade de Brasília, DF, 2004.

SANTANA, L. R. R. DE et al. Qualidade física, microbiológica e parasitológica de alfaces (Lactuca sativa) de diferentes sistemas de cultivo. Ciência. Tecnol. Aliment., Campinas, v. 26, n. 2, p. 264-269, 2006.

SANTOS, A. O. DE. Investigação epidemioparasitológica em hortaliças comercializadas em ferias livres, mercados e restaurantes do Distrito Federal. 2007. 68 f. Dissertação (mestrado em médicina veterinária) - Faculdade de Medicina, veterinária e Zootecni ,Universidade Estadual Paulista, Botucatu, São Paulo, 2007.

SANTOS, N. M.; SALES, E. M. Avaliação parasitológica de hortaliças comercializadas em supermercados e feiras livres no município de Salvador / Ba. R. Ci. méd. biol., Salvador, v. 8602, n. 2, p. 146-152, 2009.

SANTOS, T. B. A. DOS ET AL. Condições higiênicosanitárias de alfaces antes e após tratamento com agente antibacteriano. Revista Higiene Alimentar. São Paulo, v. 18, n. 121, p. 85-89, 2004.

SANTOS, Y. et al. Hygienic-sanitary quality of vegetables and evaluation of treatments for the elimination of indigenous $\mathrm{E}$. coli and $\mathrm{E}$. coli $\mathrm{O} 157$ : H7 from the surface of leaves of lettuce ( Lactuca sativa L .). Ciênc. Tecnol. Aliment., Campinas, v. 30, n. 4, p. 1083-1089, 2010.

SILVA, C. G. M.; ANDRADE, S. A. C.; STAMFORD, T. L. M. T. Ocorrência de Cryptosporidium ssp. e outros parasitas em hortaliças consumidas in natura, no Recife. Revista Científica de América Latina, el Caribe, España y Portugual - Sistema de Información Científica, v. 10, p. 63-69, 2005.

SILVA, J. PEREIRA DA et al. Estudo da contaminação por enteroparasitas em hortaliças comercializadas nos supermercados da cidade do Rio de Janeiro. Revista da Sociedade Brasileira de Medicina Tropical, v. 28, n. 3, p. 237-241, 1995.

TAKAYANAGUI, O. M. et al. Análise da cadeia de produção de verduras em Ribeirão Preto , SP Analysis of the vegetable productive chain. Revista da Sociedade Brasileira de Medicina Tropical, v. 39, n. 2, p. 224-226, 2006.

WORD HEALTH ORGANIZATION (WHO). DIET , NUTRITION AND THE PREVENTION OF Report of a Joint WHO / FAO Expert Consultation. WHO Technical Report Series. Geneva, n. 916, 2003.

XAVIER, A. Z. P. et al. Condições higiênico-sanitárias das feiras-livres do município de Governador Valadares, MG. 2009. 94 f. Dissertação (Bacharel em Nutrição) - Faculdade de Ciência da Saúde FACS, Universidade Vale do Rio Doce, Governador Valadares, MG, 2009. 